\title{
Diversity of solitary wasps and bees (Hymenoptera: Aculeata) using trap-nests in North Vietnam
}

\author{
Đa dạng các loài ong có ngòi đốt (Hymenoptera: Aculeata) sử dụng bẫy tổ ở \\ miền Bắc Việt Nam \\ Research article \\ Dang Thi Hoa* \\ Institute of Ecology and Biological Resources, Vietnam Academy of Science and Technology, 18 Hoang Quoc Viet, Cau \\ Giay, Ha Noi, Vietnam
}

\begin{abstract}
By using trap nests, a total of 1,752 nests containing 3,405 provisioned cells of 33 species of solitary wasps and bees belonging to Vespidae, Sphecidae, Crabronidae, Pompilidae and Megachilidae families were collected in North Vietnam. Although the trap-nests are placed throughout the year, the nests were only collected in the period of seven months per year, from mid-April (or early May) to early November. A larger number of the nests $(n=1,607$, or $91.72 \%)$ were occupied by wasp species and only 145 nests $(8.28 \%)$ were occupied by bee species. In each family, Vespidae, Megachilidae, Sphecidae, Crabronidae and Pompilidae were represented by 12, 11, 7, 2 and 1 species, respectively. The dominant species were Pareumenes quadrispinosus, Rhynchium bruneum (Vespidae) and Chalybion malignum (Sphecidae). The nesting activities of wasps in the summer (May to July) were more active than in the autumn (August to early November), while the highest number of nests of bees were recorded in June, October and November.
\end{abstract}

Tổng số 1.752 tổ chưa 3.405 khoang tổ của 33 loài ong bắt mồi thuộc các họ Vespidae, Sphecidae, Crabronidae, Pompilidae và ong mật họ Megachilidae đã đuợc thu thập trong bẫy tổ ở miềm Bắc Việt Nam. Mặc dù các bẫy tổ được đặt trong cả năm nhurng tổ của các loài ong bắt mồi và ong mật chỉ thu được trong khoảng thời gian tù̀ giữa tháng 4 (đầu tháng 5) đến đầu tháng 11. Phần lớn các tổ được làm bởi các loài ong bắt mồi (1.607 tồ chiếm 91,72\%), chỉ có 145 tố chiếm 8,28\% được làm bởi các loài ong mật. Số loài làm tổ thuộc các ho Vespidae, Megachilidae, Sphecidae, Crabronidae và Pompilidae tuoong únglần luợt là 12, 11, 7, 2 và 1. Trong đó có ba loài phổ biến là. Pareumenes quadrispinosus, Rhynchium bruneum (Vespidae) và Chalybion malignum (Sphecidae). Hoạt động làm tổ của các loài ong bắt mồi tù̀ tháng 5 đến 7 diễn ra tích cực hơn so với tù tháng 8 đến 11, trong khi đó số tổ của các loài ong mật lại thu được nhiều nhất trong ba tháng 6 , 10 và 11 .

Keywords: nesting activity, bees, trap nests, solitary wasps 


\section{Introduction}

Aculeate hymenopterans are essential ecosystem components, acting as pollinators and predators. They provide examples of the most sophisticated reproduction and brood caring behaviors among invertebrate animals (Ayasse et al. 2001) [1]. As they are known to be sensitive to environment changes, including anthropogenic impacts and climate change, aculeate hymenopterans may be important as bio-indicators in the study and research on conservation and management of the environment.

Most of wasps (Vespidae, Sphecidae, Pompilidae, Crabronidae) and bee (Megachilidae) are solitary (Evans \& Eberhard 1970, Batra 1984) [6, 3]. Many species of solitary wasps and bees nest in hollow stems, holes in logs, and similar natural location. Based on their behavior, the use of nest traps can provised the information with regards to life histories of some solitary bees and wasps. This method has been applied with great success since the mid twenty century in collecting the specimens and studing biology and ecology (Krombein, 1967; Gathmann et al., 1994; Budriene, 2004; Barthélémy, 2012) [10, 7, 5, 2]. Tthis report aims to provide the species composition and the changes in nesting frequency over time of Aculeate hymenopterans using the trap-nests in North Vietnam.

\section{Materials and methods}

\subsection{Study sites}

The field research was carried out in North Vietnam during 2013-2014 in 7 sites (table 1).

Table 1. Time and study sites

\begin{tabular}{|c|c|c|c|c|}
\hline No. & Study sites & Years of sampling & Coordinates & Altitude \\
\hline 1 & $\begin{array}{l}\text { Nghia Hung District, Nam Dinh Prov- } \\
\text { ince (NH) }\end{array}$ & 2014 & $20^{\circ} 4.9^{\prime} \mathrm{N} 106^{\circ} 11.8^{\prime} \mathrm{E}$ & $1 \mathrm{~m}$ \\
\hline 2 & $\begin{array}{l}\text { Dong Hung District, Thai Binh Prov- } \\
\text { ince (DH) }\end{array}$ & 2014 & $20^{\circ} 31.1^{\prime} \mathrm{N} 106^{\circ} 19.6^{\prime} \mathrm{E}$ & $2 \mathrm{~m}$ \\
\hline 3 & $\begin{array}{l}\text { Red River Delta, Long Bien District, } \\
\text { Ha Noi city (RR) }\end{array}$ & 2013-2014 & $21^{\circ} 03^{\prime} \mathrm{N} 105^{\circ} 51^{\prime} \mathrm{E}$ & $10 \mathrm{~m}$ \\
\hline 4 & $\begin{array}{l}\text { Me Linh Station for Biodiversity, } \\
\text { Ngoc Thanh District, Vinh Phuc Prov- } \\
\text { ince (ML) }\end{array}$ & $2013-2014$ & $21^{\circ} 23^{\prime} \mathrm{N} 105^{\circ} 42^{\prime} \mathrm{E}$ & $50 \mathrm{~m}$ \\
\hline 5 & $\begin{array}{l}\text { Phu Luong District, Thai Nguyen } \\
\text { Province (PL) }\end{array}$ & 2014 & $21^{\circ} 48^{\prime} \mathrm{N} 105^{\circ} 44.5^{\prime} \mathrm{E}$ & $73 \mathrm{~m}$ \\
\hline 6 & $\begin{array}{l}\text { Tam Dao Town, Vinh Phuc Province } \\
\text { (TD1) }\end{array}$ & $2013-2014$ & $21^{\circ} 26.5^{\prime} \mathrm{N} 105^{\circ} 37^{\prime} \mathrm{E}$ & $400 \mathrm{~m}$ \\
\hline 7 & $\begin{array}{l}\text { Tam Dao Town, Vinh Phuc Province } \\
\text { (TD2) }\end{array}$ & $2013-2014$ & $21^{\circ} 27.5^{\prime} \mathrm{N} 105^{\circ} 38.5^{\prime} \mathrm{E}$ & $960 \mathrm{~m}$ \\
\hline
\end{tabular}

\subsection{Nest traps}

A total of 4,700 trap nests were placed at the Red River Delta $(n=500)$, Me Linh $(n=1,500)$, Tam Dao $(n=2,000)$, Dong Hung $(n=200)$, Nghia Hung $(n=200)$ and Phu Luong $(\mathrm{n}=300)$. The trap nests, made from stems of bamboo, Bambus sp. and reed, Phragmites sp. (130 to $550 \mathrm{~mm}$ long and 3 to $18 \mathrm{~mm}$ in inner diameter, with one end open and the other end closed with the node) were grouped in bundles with 15 to 35 stems each. The nest traps were placed nearly horizontally under eaves and in wire-mesh fences and hung from tree branches, at height of 0.8 to 3.5 $\mathrm{m}$ (figs 1 and 2). The trap-nests were checked every one to three weeks during the activity period of wasps and bees (from April to November in North Vietnam).
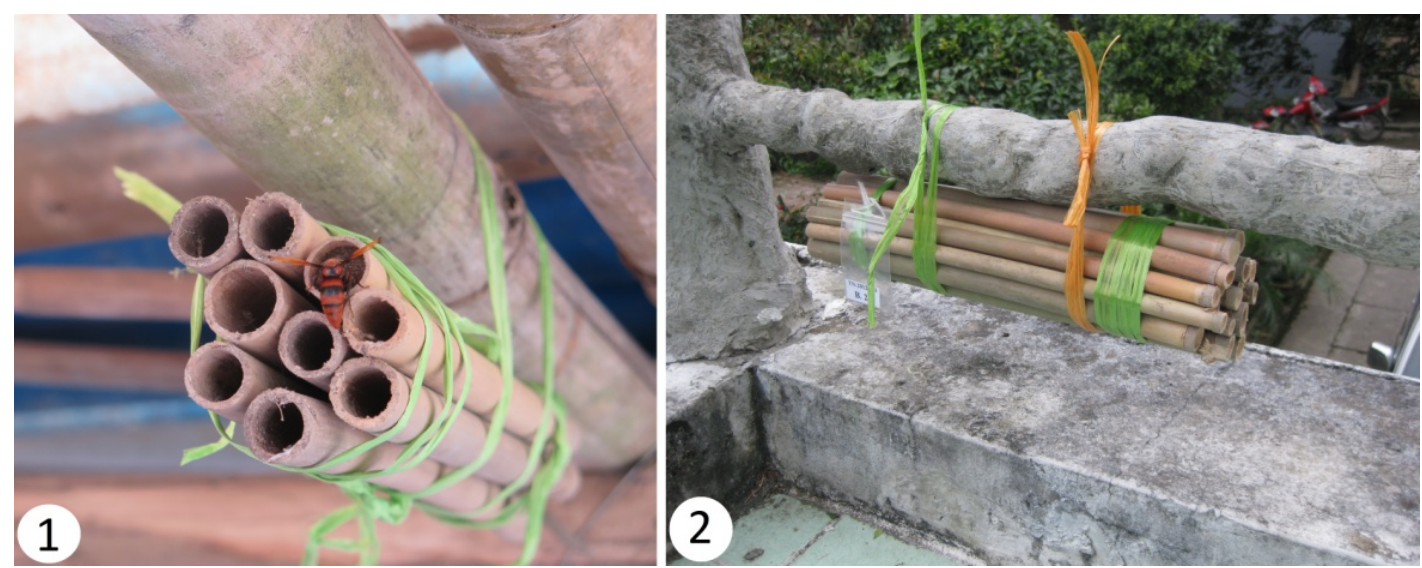

Figures 1, 2. Nest traps set under eaves at the Red River Delta (1) and wire-mesh fences at Tam Dao (2) 
Nest traps with the closing plug were taken to the IEBR laboratory in Hanoi for further observation. They were kept at room temperature and were opened by gently splitting longitudinally into two halves for the examination of the structure and contents (immatures of wasps, preys and symbionts) of the nests and then were closed again by joined these halves together. Everyday, the nests were checked. The developmental stages (eggs, larval instars, prepupae, pupae) of immatures in provisioned cells were examined under a stereoscopic microscope; prey items were identified and counted; the emergence of symbionts such as parasitic wasps was also recorded.

The naming of wasps and bees were based on Bingham, 1897; Hensen, 1988; Giordani Soika 1994; Nguyen, 2015; Palawski, 2016; van der Vecht 1963 [4, 9, 11, 12, 13].

\section{Results and discussion}

The 1,752 nests comprised 3,405 provisioned cells and yielded data for 33 species of solitary bees and wasps in five families, Vespidae (Eumeninae), Sphecidae, Crabronidae, Pompilidae and Megachilidae. Refer to table 2 for a summary of the trap data. Twenty-two wasp and eleven bee species were collected, large number of the nests $(\mathrm{n}=$ 1,607 nests or $91.72 \%$ ) were occupied by wasp species; bee species occupied 145 nests, or $8.28 \%$. The number of trap-nests occupied by solitary bees and wasps as found in our study was relatively high compared with data obtained Barthélémy's study in Hong Kong.

Table 2. List of cavity-nesting Hymenoptera species collected using trap-nests in North Vietnam

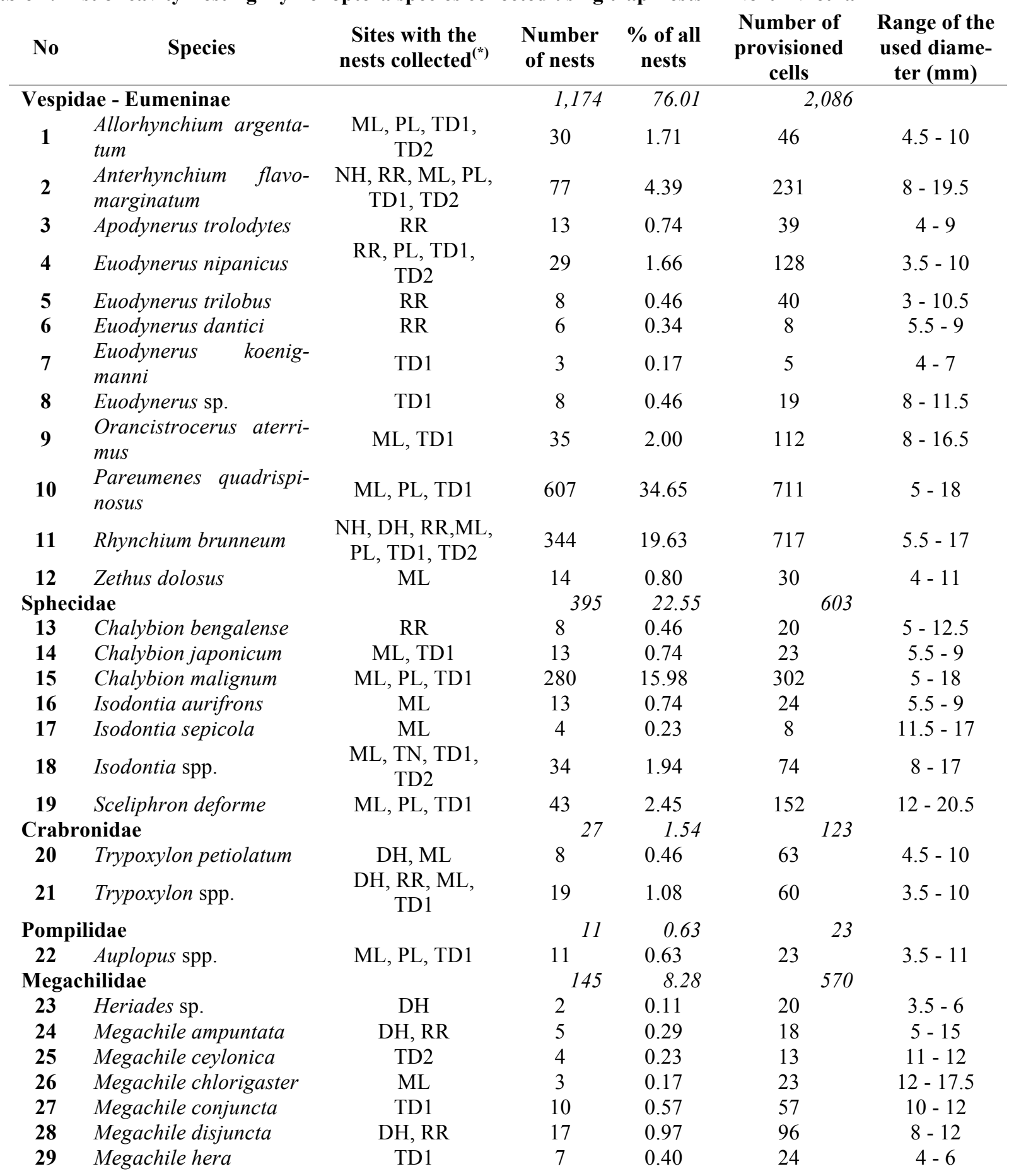




\begin{tabular}{|c|c|c|c|c|c|c|}
\hline No & Species & $\begin{array}{l}\text { Sites with the } \\
\text { nests collected }^{(*)}\end{array}$ & $\begin{array}{l}\text { Number } \\
\text { of nests }\end{array}$ & $\begin{array}{c}\% \text { of all } \\
\text { nests }\end{array}$ & $\begin{array}{l}\text { Number of } \\
\text { provisioned } \\
\text { cells }\end{array}$ & $\begin{array}{l}\text { Range of the } \\
\text { used diame- } \\
\text { ter (mm) }\end{array}$ \\
\hline 30 & Megachile lanata & TD1 & 1 & 0.06 & 9 & 9.5 \\
\hline 31 & Megachile monticola & ML & 2 & 0.11 & 10 & $12-15$ \\
\hline 32 & Megachile velutina & ML, TD1 & 29 & 1.66 & 94 & $7-14$ \\
\hline \multirow[t]{2}{*}{33} & Megachile spp. & $\begin{array}{l}\text { RR, ML, PL, } \\
\text { TD1, TD2 }\end{array}$ & 65 & 3.71 & 206 & $3-16$ \\
\hline & Total & & 1.752 & 100 & 3,405 & \\
\hline
\end{tabular}

${ }^{(*)}$ NH: Nghia Hung District, Nam Dinh Province; DH: Dong Hung District, Thai Binh Province; RR: Red River Delta, Long Bien District, Ha Noi city; ML: Ngoc Thanh District, Vinh Phuc Province; PL: Phu Luong District, Thai Nguyen Province; TD1: Tam Dao Town, Vinh Phuc Province, altitude 400m; TD2: Tam Dao Town, Vinh Phuc Province, altitude 960m.

Although the trap nests were placed throughout the year, the nests were only collected in the period of seven months per year, from mid-April (or early May) to early November (fig. 3), with occupation peaks in May and June (nearly $50 \%$ of total nests). The lowest occupation occurred in April and November. The nesting activities of wasps in the summer (May to July) were more active than in the autumn (August to early November), while the highest number of nests of bees were recorded in June, October and November.

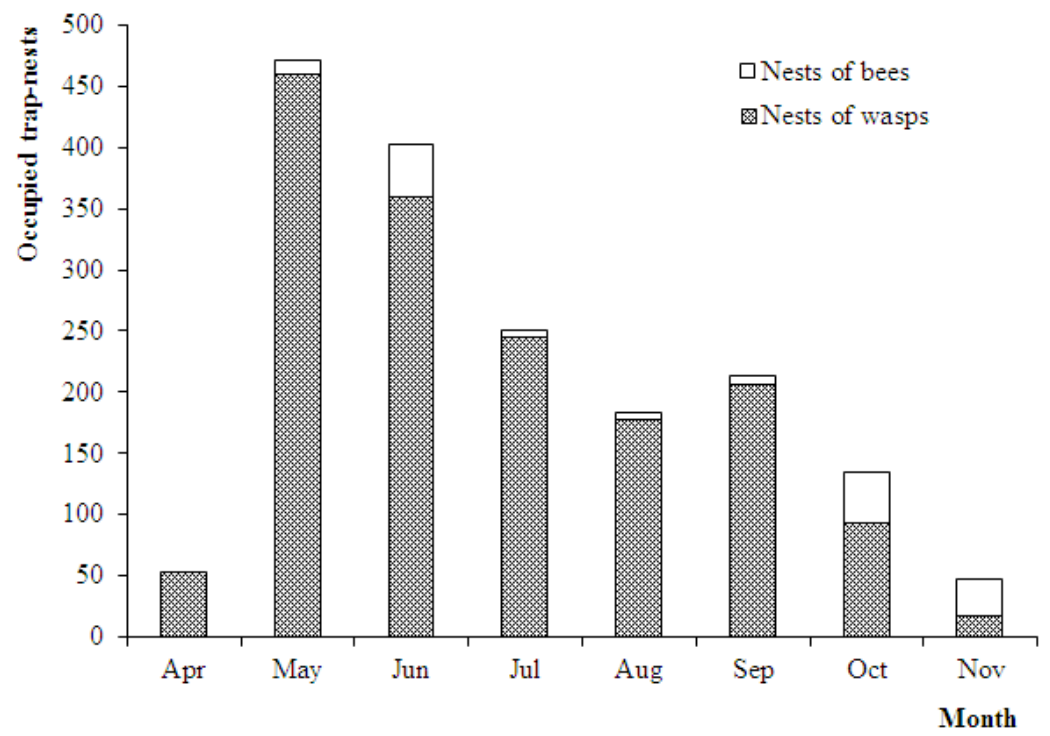

Figure 3. Occupation frequency of trap-nests by solitary wasps and bees

Twelve species of eumenid wasps belonging to genera Pareumenes, Rhynchium, Anterhynchium, Orancistrocerus, Apodynerus, Euodynerus, Zethus, Allorhynchium occurred in considerable number in the trap-nests. All species provisioned their cells with caterpillars, the number of preys in a cell was considered to depend on the size, the kind of preys and the wasps. The dominant species were $P$. quadrispinosus, $R$. bruneum (1,428 provisioned cells, represent $68.45 \%$ of total collected specimens); but two species comprising $R$. brunneum and $A$. flavomarginatum widely distributed, they were collected at all site setting trap-nests.

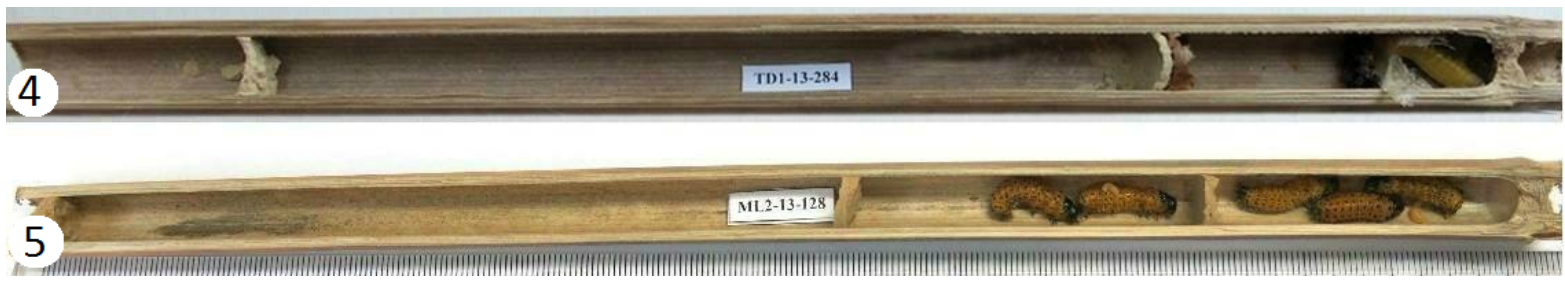

Figures 4,5. Pareumenes qudrispinosus. Content of the nest at opening: The nest containing a prepupa (4) and the nest containing two provisisoned cells with lavae and preys (5) 

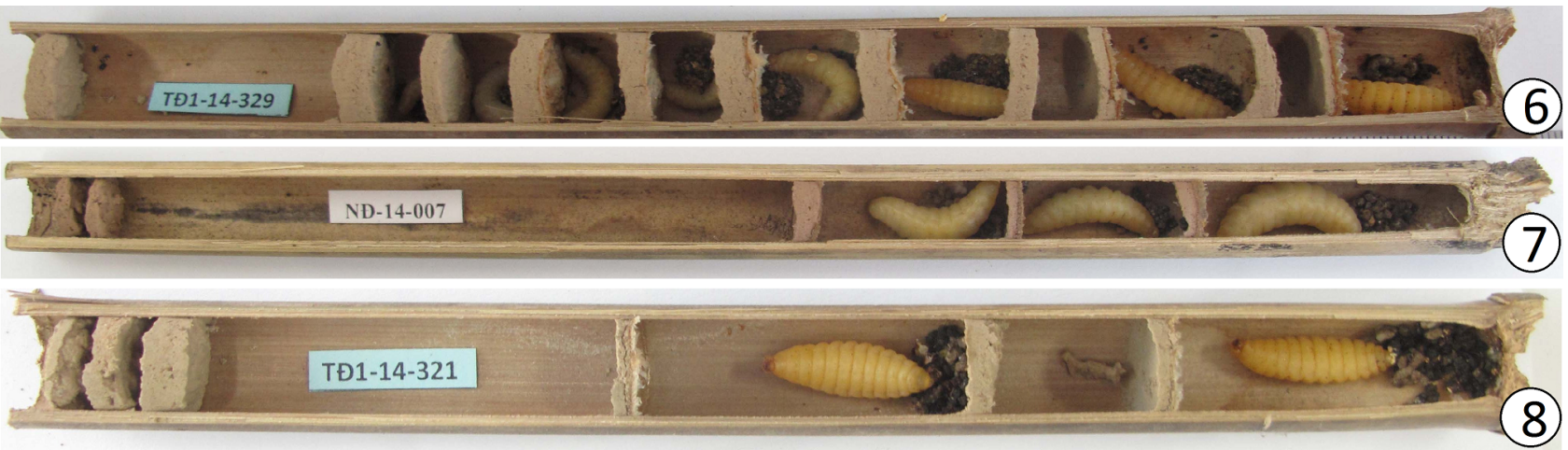

Figures 6-8. The opening nests of Rhynchium brunneum.

Compared with the results of Barthélémy (2012) [2], the number of eumenid species collected by trapping in North Vietnam (12 species) is more abundant than in Hong Kong ( 7 species). Between the two studies there was a representative match between the five genus, Allorhynchium, Anterhynchium, Apodynerus, Pareumenes and Zethus. Two genera Pararrhynchium and Xenorhynchium obtained in Hong Kong were not recorded in our study. In contrast, genera Euodynerus, Orancitroserus and Rhynchium were not seen in the tra-nests in Hong Kong. In our study, $P$. quadrispinosus and $R$. brunneum were the dominant species (951 nests containing 1,428 provisioned cells), but in Hong Kong the number of nests of these species were very small (only 6 nests containing 6 provisioned cells of $P$. quadrispinosus) or even absent.

Seven species of sphecid wasps, Chalybion malignum (Kohl, 1906), Chalybion bengalense (Dahlbom, 1845), Chalybion japonicum (Gribodo, 1883), Isodontia aurifrons (Smith, 1859), Isodontia sepicola (F. Smith, 1859), Isodontia spp., Sceliphron deforme Smith, 1856, were found at five among 7 site setting trap-nests. The females of genera Chalybion and Sceliphron provisioned their cells with spider, while, the females of genus Isodontia provisioned the crickets, locusts and stickers for their broods. The dominant species was C. malignum (280 nests, 302 provisioned cells). This species occurs continuously from mid-April to mid-September with the highest number of nests in May and July, while in other months they maintained low population density. The number of trap-nests occupied by sphecid wasps as found in North Vietnam ( 7 species) was nearly double compared with data obtained in Hong Kong (4 species).
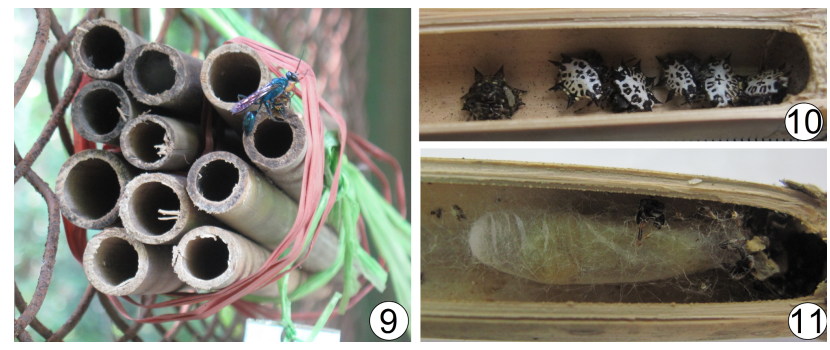

Figures 9-11. Chalybion malignum. A female is picking her prey (9); a cell with larva and preys (10); $5^{\text {th }}$ larva is spining cocoon (11)
Eleven species of megachilid bees belonging to genera Megachile and Heriades were found in trap-nests. The nests of different species were collected at different altitudes; $M$. ceylonica was found at high altitude $(960 \mathrm{~m})$ at the centre of the Tam Dao National Park; M. conjuncta, $M$. hera and M. lanata were found at lower height at the Tam Dao National Park (400 m); M. chlorigaster and $M$. monticola only were found at Me Linh, the buffer zone of the Tam Dao National Park $(50 \mathrm{~m})$; Nests of $M$. velutina were collected both at Me Linh and the lower site in Tam Dao; M. ampuntata, M. disjuncta and Heriades sp. were collected at the agro-ecosystems or small gardens (Red River Delta and Dong Hung). All used pollen and nectar to provision their cells. The dominant species was $M$. velutina; most of the nests were collected in October and November (27 nests, 87 provisioned cells).

Compared with the results of Barthélémy (2012) [2], the number of bee species collected by trapping in North Vietnam is more abundant than in Hong Kong. Genus Megachile was recorded in both studies. Two genera Chalicodoma (Megachilidae) and Hylaeus (Colletidae) obtained in Hong Kong were not recorded in our study.
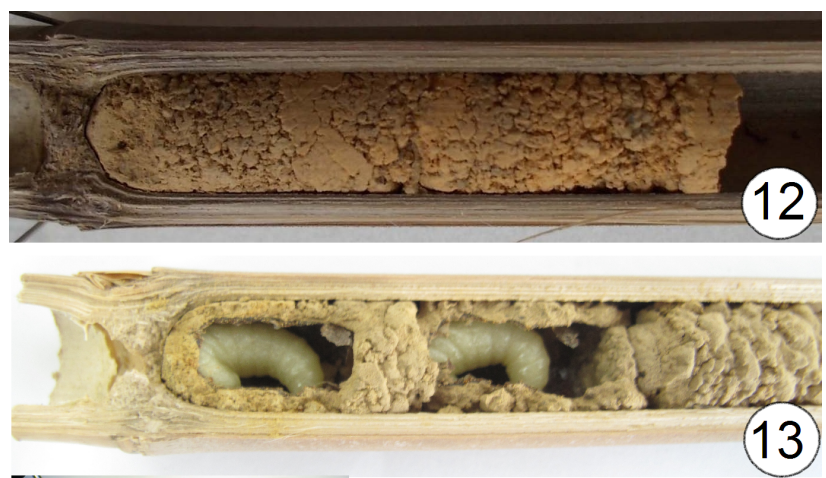

Figures 12-13. Megachile velutina. Two cells in opening nest (12) and two prepupae (13)

\section{Conclusion}

The wasp and bee communities inhabiting trap-nests in North Vietnam include up to 33 species. The nests were collected in the period from mid-April (or early May) to early November. Most of them are diapause as prepupae during the winter (last November to early next April). The number of species recorded in each site de-pends on land- 
scapes and habitats. The number of species collected in the natural forest (Me Linh and Tam Dao) is more abundant at the agro-ecosystems or small gardens (Red River Delta Nghia Hung and Dong Hung). The female of bees and wasps provisioned nectar and pollen, caterpillars, spiders, crickets, locusts and stickers for their broods. So, the using trap nests are recommended as a means of augmenting the number of bees and wasps as well as control the pests of crop and augmentation of the croppollinating.

Acknowledgement: Our thanks go to Nguyen Thi Phuong Lien, Pham Huy Phong and Tran Thi Ngat for confirming the identification the specimens of family Vespidae, Sphecidae and Megachilidae; to Trinh Xuan Thanh, Nguyen Dac Dai, Nguyen Tien Dat for their help in field research at Me Linh Station for Biodiversity. The present study was financially supported by the Japan Society for the Promotion of Science (Dissertation PhD Program No. VAST-11325).

\section{References}

[1] Ayasse, M., Paxton, R.J. and Tengo, J., 2001. Mating bihavior and chemical communication in the order Hymenoptera. Annual Review of Entomology 46: 31-78.

[2] Barthélémy, C., 2012. Nest trapping, a simple method for gathering information on life histories of solitary bees and wasps. Bionomic of 21 species of solitary aculeate in Hong Kong. Hong Kong Entomological Bulletin, 4(1): 3-37.

[3] Batra, S.W., 1984. Solitary bees. Scientific American, 250: 86-93.

[4] Bingham, C. T., 1897. The Fauna of British India, including Ceylon and Burma: Hymenoptera, Vol. 1, Wasps and Bees. Taylor and Francis, London, 579 pp.
[5] Budriene, A., 2004. Reproductive ecology and behaviour of predatory wasps (Hymenoptera: Eumeninae). Doctoral thesis. 152pp.

[6] Evans, H.E. \& Eberhard M.J.W., 1970. The wasps. Ann Arbor, the University of Michigan Press, Michigan, 265p.

[7] Gathmann A., Greiler H.J., Tscharntke T., 1994. Trap-nesting bees and wasps colonizing set-aside fields: succession and body size, management by cutting and sowing. Oecologia 98: 8-14.

[8] Giordani Soika, A., 1994. Nota sulle specie orientali del genere RhynchiumSpinola (Hymenoptera, Eumenidae). Lavori Societa veneziana di Scienze naturali 19: 37-52.

[9] Hensen, R.V., 1988. Revision of the nominate subgenus Chalybion Dahlbom (Hymenoptera, Sphecidae). Tijdschrft voor Entomologie., 131: 13-64.

[10] Krombein, K. V., 1967. Trap-nesting Wasps and Bees: Life histories, nests and associates. Smithsonian Press, 570pp.

[11] Nguyen Thi Phuong Lien, 2015. Taxonomic notes on the species of the genus Anterhynchium de Saussure, 1863 (Hymenoptera: Vespidae: Eumeninae) from Vietnam with description of a new species. Zootaxa 3915 (1): 132-138.

[12] Pulawski, W.J., 2016. Number of species in Sphecidae (sensu lato). Downloaded from $\mathrm{http} / /$ research.calacademy. org/sites/research.calacademy.org/files/Departments/ ent/Sphecidae/Genus_of_Chalybion.pdf).

[13] Vecht J. van der, 1963. Studies on Indo-Australian and East-Asiatic Eumenidae (Hymenoptera, Vespoidea). Zoologische Verhandelingen, Leiden 60: 3-113. 